UDC 636.2.034

Review paper

doi: 10.5937/AASer1846265L

Acta Agriculturae Serbica, Vol. XXIII, 46 (2018); 265-276

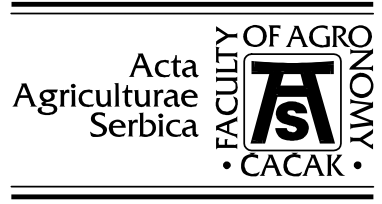

\title{
Lipolysis and ketogenesis in cows in early lactation (Review)
}

\author{
Ivana Lakić ${ }^{1}$, Marko R. Cincović ${ }^{1}$, Branislava Belić ${ }^{1}$, Radojica \\ Đoković $^{2}$, Mira Majkić ${ }^{1}$, Miloš Ž. Petrovićéc, Sandra Nikolić ${ }^{1}$ \\ ${ }^{1}$ University of Novi Sad, Faculty of Agriculture, Department of Veterinary \\ Medicine; Trg Dositeja Obradovića 8, 21000 Novi Sad, Serbia \\ ${ }^{2}$ University of Kragujevac, Faculty of Agronomy Čačak, Cara Dušana 34, Čačak, \\ Serbia \\ Corresponding author: mcincovic@gmail.com
}

\begin{abstract}
Peripartal metabolic stress is characterized by increased lipid mobilization, when non-esterified fatty acids (NEFA) are increased, as well as by increased ketogenesis, when the concentration of beta-hydroxybutyrate (BHB) is increased. NEFA are metabolized in all tissues but the main organ is the liver. Possible processes are: a) complete oxidation of NEFA, b) partial oxidation and synthesis of ketone bodies (BHB), c) development of triglycerides from NEFA that can be transported or stay in the liver when fatty liver is apparent. Moreover, increased lipolysis and ketogenesis can cause oxidative stress because concentrations of MDA and/or TBARS are positively correlated with NEFA and BHB concentrations. The increase in NEFA during the peripartal period affects the cellular immunologic response by changing intracellular signals, gene expressing control, activation of transcriptional factors, apoptosis induction and by modifying mediators of lipid production. Increased proportion of cows with high NEFA and BHB concentrations in the herd can cause reduced milk yield at the end of a standard 305-day lactation. NEFA concentrations can be related to postpartal ovarian activity, especially given that blood NEFA concentrations represent NEFA concentrations in the ovarian follicular fluid. Cows on farms with lower scores of animal welfare and nutrition have higher concentrations of cortisol, NEFA, BHB, bilirubin, glucose and urea. NEFA and BHB concentrations in early lactation can be used for estimating metabolic adaptation in the first 8 weeks after calving. For the estimation of metabolic adaptation, increased lipolysis has a greater significance than decreased anabolic parameters.
\end{abstract}

Received 27 November 2018 Accepted 14 December 2018 
Keywords: lipolysis, metabolic profile, early lactation, stress.

\section{Lipolysis and ketogenesis physiology}

Peripartal metabolic stress is accompanied by negative energy balance, using fats for energy needs of peripheral tissues and glucose for milk production (Cincović, 2016, Cincović and Starič Ed., 2017). This metabolic shift reduces glucose concentrations and increases non-esterified fatty acid (NEFA) concentrations. High NEFA concentrations lead to a higher production of ketone bodies in the liver when beta-hydroxybutirate (BHB) concentration in the blood is increased. Metabolic indicators of poor energy status in cows are: lower glucose concentrations, higher NEFA and BHB concentrations. This metabolic profile is typical of the peripartal period in cows, and in many cows this parameters are significantly outside the reference range (Cincović et al., 2011).

Glucose, NEFA and BHB are significantly correlated with negative energy balance during lactation. Therefore, their concentrations depend on the period of lactation and to a lesser extent on energy balance. Cows fed diets with lower energy values in different periods of lactation showed the following metabolic specifics: energy deficit was highly expressed in the second trimester of lactation compared to early lactation, but glucose concentration was significantly lower and NEFA and BHB higher in early lactation. This shows that glucose, NEFA and BHB concentrations in early lactation are wider metabolic regulations which, inter alia, include negative energy balance (Gross et al., 2011).

Reduced glucose concentration in cows is due to reduced feed intake and a higher shift of glucose to the milking gland and gravid uterus (Bell and Bauman, 1997). Glucose concentrations showed a tendency for a sudden decrease in the period around partus. When lactation starts, glucose needs are highly increased. Cows in this period can satisfy only $10 \%$ of glucose needs through feed. Therefore, gluconeogenesis is the main mechanism of regulation of glucose concentrations. Homeorhetic adaptations of glucose metabolism during lactation are manifested by greater hepatic gluconeogenesis. It has been showed that, in the peripartal period, propionate, lactate, alanyl and glycerol have major effects on glucose production in the liver. Propionate is synthesized by ruminal fermentation, lactate is from the Cory cycle, amino acids are from protein metabolism and glycerol is from catabolism in fat tissue. During the peripartal period, propionate, amino acids, lactate and glycerol account for 50-60\%, 20$30 \%, 15-20 \%$ and $2-4 \%$, respectively, of net glucose production. Intravenous administration of propionate in healthy cows can cause a major increase in glucose concentration (2-2.5x) in the first hour after injection. Cows with ketosis, which is related to a compromised liver status, exhibit a reduced glucose production, which indicates the significance of the liver in gluconeogenesis 
(Đoković et al., 2007). For that reason, the administration of propionate can significantly improve metabolism in the peripartal period (Cincović et al., 2010).

Considering metabolic regulations in the peripartal period, glucose concentration is inversely proportional to NEFA and BHB concentrations. Free fatty acids, NEFA in the circulation are complexed with albumins and represent the alpha-lipoprotein fraction. Gas chromatography proved that NEFA in the blood consist of 12 free fatty acids, dominated by palmitic, stearic, and linoleic acid (Husvéth et al., 1982). Hydrolysis of triglycerides in fat tissue is the main process that causes lipid mobilization and increases fatty acids. Palmitic flow measurements showed that cows in the peripartal period can mobilize up to 2.9 $\mathrm{kg}$ of fats (Konig et al., 1979). The use of fatty acids for energy is the most important homeorhetic mechanism in early lactation. NEFA in the blood come from lipid mobilization in fat tissue and catabolism of fat that is caused by many endocrine regulations and reduced feed intake. Reduced feed intake alone is not enough to start lipid mobilization (Friggens et al., 2003). However, NEFA can be very sensitive indicators of nutrient supplies. Considering that NEFA have diurnal variations, their concentrations are highest at night and in the morning (because cows do not consume feed during the night). Under heat stress, NEFA are higher in warmer parts of the day when cows reduce feed intake (Bertoni et al., 2002; Cincović et al., 2010).

NEFA are metabolized in all tissues but the main organ is the liver. Metabolic processes of NEFA are: a) complete oxidation of fatty acids to water and carbon dioxide b) partial oxidation to acetyl coenzyme A and synthesis of ketone bodies (BHB), c) formation of triglycerides from NEFA and their transport in the form of VLDL lipoproteins from the liver, d) re-synthesis of triglycerides in the liver and their accumulation and fatty degeneration of the liver. Examinations have shown that changes at the receptor and genomic level in the liver cause adequate or inadequate adaptations that cause the development of metabolic diseases (Loor et al., 2007). Accordingly, the liver is the central metabolic organ during the peripartal period. Synthesis of ketone bodies and triglyceride re-synthesis in the liver are the basis for the development of peripartal diseases such as ketosis and fatty liver that are related to general health condition and production in the lactation period.

NEFA and BHB are poorly variable values and show a high diagnostic significance in evaluating metabolic and health status in cows. Glucose is a moderately variable value, as is its diagnostic value. The latest tendency in science has been to determine the most important concentrations of glucose, NEFA and BHB and their predictive values in health and production evaluations. NEFA concentrations above $0.4 \mathrm{mmol} / \mathrm{l}$ and $0.8 \mathrm{mmol} / \mathrm{l}$ in the first week after calving and BHB concentrations above $1.2 \mathrm{mmol} / \mathrm{l}$ in the first or/and second week after calving are mainly measured in cows that developed peripartal diseases; therefore, the predictive role of this metabolites has been shown. Scientists have shown that NEFA have a more important predictive role. For 
subclinical ketosis, the optimal predictive value for NEFA is lower (0.26 $\mathrm{mmol} / \mathrm{l})$. Glucose concentration is not a statistically significant predictor of health and productivity of cows but its value below $2.3 \mathrm{mmol} / \mathrm{l}$ can indicate the development of different diseases (Ospina et al., 2010a, b; Nawroozi et al., 2011; Roberts et al., 2012). Prolonged hyperketonemia and high NEFA concentrations have negative effects on many aspects of adaptation of milking cows to peripartal metabolic stress (Hachenberg et al., 2007; Kessel et al., 2008; Cincović et al., 2012). For the sake of comparison: NEFA concentrations of $0.3-0.5 \mathrm{mmol} / \mathrm{l}$ show increased lipid mobilization, but values over $0.7 \mathrm{mmol} / \mathrm{l}$ show a great amount of lipid mobilization (Šamanc, 2009).

The response of hypothalamic-pituitary-adrenal glands and adaptation capacity of cows are correlated with glucose and NEFA concentrations in early lactation. If glucose concentration is decreased, the response of the stress axis will be intense, focusing on the response of the hypothalamus and the hypophysis . High NEFA concentrations will cause reduced response of the adrenal glands to ACTH. Based on this, these metabolites affect different stress axes in the organism and adaptation of cows to peripartal stress (Beerda et al., 2004).

\section{Lipolysis. ketogenesis, metabolic adaptation and health of cows}

Our results (Cincovic et al., 2012) have shown that cows in fat catabolism load before and after calving have the following characteristics during the first 8 weeks after calving: lower glucose concentrations (week 1, 4), lower cholesterol concentrations (8), lower total protein concentrations (1, 2), lower urea concentrations $(1,2,4,8)$, higher bilirubin concentrations $(-1,1,2,4,8)$, increased activity of AST $(-1,1)$ and ALT $(-1,2)$, reduced Ca levels $(-1)$, lower levels of hemoglobin $(-1)$, reduced leucocyte count (4), increased neutrophil count $(-1,1,2)$ and increased levels of lymphocytes (4). The factor analysis and the main component method showed that NEFA, BHB and glucose are the main components that affect the metabolic profile and blood test results, making up $71 \%$ of all parameter variability. Cows with hypoglycaemia, hypocalcaemia, hypoalbuminaemia, hyperbilirubinaemia, lower hemoglobin concentrations and/or reduced erythrocyte count and ratio neutrophils:lymphocytes $>1$ have higher concentrations of NEFA and BHB compared to cows with these parameters within the reference range.

Recent results of Belić et al. (2018) have shown that the combination of anabolic and catabolic indicators of metabolism in the first week after calving can be used to evaluate metabolic status in the first week of early lactation. Change of values of metabolic parameters is determined by greater lipid mobilization i.e. lipid catabolism, when the decrease in anabolic parameters such as insulin and IGF-I is of smaller significance for the development of peripartal metabolic adaptation in cows. 
It has been found that the optimal use of proteins in the organism is based on adequate levels of energetic compounds in the feed such as long chain fatty acids, but increased levels of endogenous long chain fatty acids such as NEFA have a bad influence (Reynolds et al., 1998; Drackley, 1999). Some results showed a correlation between NEFA and urea concentrations in early lactation, depending on the week of blood sampling (Rastani et al., 2006).

Cows with induced ketosis have a reduced capacity for gluconeogenesis and reduced activityies of glucose-6-phosphatase and pyruvate-carboxylase (Murondoti et al., 2004; Loor et al., 2007). There are still ongoing discussion on which enzymes are involved in lipid metabolism and their shift to oxygenation i.e. re-esterification. Mitochondrial forms of glycerol phosphate acyl transferase (mGPAT) are very significant for acylglycerol synthesis. Livers iRNK for mGPAT is reduced in the dry period of cows and its production increases from calving to day 14 of lactation (Loor et al., 2005). Similar results are found for microsomal activity of diacylglycerol-acyl-transferase enzyme (the only enzyme that is specific for triglyceride synthesis in the liver). No difference was found between healthy controls and cows with fatty liver (Van Den Top et al., 1996). This indicated that, in pathophysiological terms, beta-oxidation of NEFA and ketogenesis have a greater influence on the functional status of the liver (Drackley et al., 2005).

The relationship between NEFA and cholesterol values is used as an indirect sign of fatty liver in cows (VanSaun, 2000). Many metabolites are correlated with the degree of fatty liver in cows (Đoković et al., 2011).

In addition to the enzymatic and receptor/ genomic bases for lipid accumulation and ketogenesis the liver, a natural characteristic of ruminants is that they contain low levels of VLDL lipoproteins (VLDL, Very Low Density Lipoproteins) in the blood. These lipoproteins have a crucial role in triglyceride transport from the liver to other tissues and milk glands. In the peripartal period, the liver has a limited capacity for VLDL synthesis, as manifested in great lipid mobilization. The transport role of VLDL is particularly pronounced, considering that ruminants have significantly reduced chilomycron concentrations and that the half-life of VLDL is very short 2-11 minutes. This limits the transport of triglycerides (Yamamoto et al., 1995). Changes in the transcription and posttranscription of proteins that are contained in VLDL cause lipid infiltration of the liver (Dann and Drackley, 2005). Greater lipid mobilization and lipid metabolism in the liver with reduced capacity of the liver to produce transport forms of lipoproteins cause lipid accumulation in the liver, fatty infiltration and fatty degeneration, which have negative effects on the health and productivity of cows. The worst form of this disease is hepatic coma known also as gravidic toxemia, which is lethal in most cases. Non-esterified fatty acids are reactive molecules which are prone to oxidation and reactions with free radicals. Fats are considered the best indicators of oxidative stress (Georgieva, 2005). Malondialdehyde (MDA) is a product of the reaction between free radicals and 
half-sized fatty acids. It acts very rapidly with thiobarbituric acid, giving the reactive substances of thiobarbituric acid (TBARS). The concentrations of MDA and/ or TBARS are significantly higher in the period after calving in milking cows and are positively correlated with NEFA and BHB concentrations (Bernabucci et al., 2002, 2005).

As the antioxidant capacity of cows depends on the energy balance of cows, negative energy balance in ketotic cows results in reduced antioxidant activity and greater concentrations of lipid reactive molecules. Antioxidative protection also depends on nutrition and milk production in cows. Calving also affects antioxidative systems, and the concentration of antioxidant substances is reduced in early lactation (Adela et al., 2006, Pedernera et al., 2010; Zhang et al., 2011).

For the examination of the relationship between metabolic stress and hypocalcaemia, it should be noted that hypocalcaemia reduces insulin secretion and glucose use in peripheral tissues (Littledike et al., 1997). This state induces lipid mobilization and increases metabolic stress. In ketotic cows, the concentration of inorganic phosphorus is reduced.

Increased NEFA concentrations in the peripartal period cause changes in the cellular immune response by modification of intracellular signals, control of gene expression, activation of transcription factors, apoptosis induction and modified production of lipid mediators. Changes in serum NEFA constituents can directly affect phospholipid constituents in leucocytes, which reduces their function (Contreras et al., 2010). During the peripartal period, greater lipid mobilization occurs especially in fat cows. Obese cows show significant signs of immunosuppression in the peripartal period, which is reflected in the negative relation between NEFA concentrations and the functional status of peripheral mononuclear cells (lower levels of immunoglobulins and interferon gamma are produced, DNA synthesis is decreased). Apart from mononuclear cells, polymorphonuclears are also sensitive to increased concentrations of NEFA. It has been shown that in vitro addition of NEFA can affect neutrophils by reducing their viability and by increasing oxidative load (Scalia et al., 2006). Oxidative stress can cause gene activation, which determines the production of proinflammatory cytokines. Increased amounts of these mediators can cause the development of unspecific inflammatory processes in tissues that are related to mastitis or metritis in cows in the peripartal period. Lipid peroxidation products can increase the proinflammatory phenotype of cells (Sordillo et al., 2009). The expression of the proinflammatory phenotype can cause cell apoptosis and reduced viability, resulting in a reduced immune response. Apoptosis and reduced viability are found in mononuclears and polymorphonuclears. DNA damage underlies these processes (Tharwat et al., 2012).

Body condition is an indirect sign of the metabolic status of cows. In one experiment, cows were divided in two groups with two subgroups: obese cows and skinny cows. Each group contained a subgroup of cows that lost body condition and group that did not lose body condition in the peripartal period. 
Obese cows with an intensive decrease in body weight showed the highest concentrations of NEFA, BHB and bilirubin and the lowest levels of glucose and insulin (Šamanc et al., 2015). These cows showed differences compared to obese cows that retained their body weight and skinny cows. This showed that obese cows are at risk of developing insulin resistance, which depends not only on body weight but also on the intensity of losing body condition (Busato et al., 2002).

\section{Lipolysis, ketogenesis and production characteristics of cows}

The relationship between metabolic parameters and productive characteristics of cows was investigated in our experimental conditions (Cincović et al., 2014; Belić et al., 2014)

Many investigations showed the association between some metabolites and milk production in early lactation. NEFA concentrations $\geq 0.5 \mathrm{mEq} / \mathrm{L}, \mathrm{BHB} \geq 600$ $\mu \mathrm{mol} / \mathrm{L}$ and calcium $\leq 2.1 \mathrm{mmol} / \mathrm{L}$ can decrease milk production by $1.6-3.2 \mathrm{~kg}$ each day in early lactation. High levels of NEFA and BHB in the first and second week after calving $\ell 0.7$ and $\geq 1.0 \mathrm{mEq} / \mathrm{L}$ for NEFA, $\geq 1.4$ and $\geq 1.2 \mu \mathrm{mol} / \mathrm{L}$ for $\mathrm{BHB})$ and low calcium levels $(\leq 2.1 \mathrm{mmol} / \mathrm{L})$ in the first three weeks after calving are associated with reduced milk production in early lactation (Chapinal et al., 2012). Higher proportion of cows with increased concentrations of NEFA and $\mathrm{BHB}$ in the herd can cause a reduction in milk production in a standard 305-day lactation (Ospina et al., 2010a, b). Increased concentrations of NEFA and BHB can have a negative influence on milk gland status, which can cause mastitis in early lactation along with reduced milk yield (Suriyasathaporn et al., 2000; Holtenius et al., 2004).

NEFA concentrations can be related to postpartal ovarian activity especially considering that NEFA blood concentrations reflect NEFA concentrations in the ovarian follicular fluid. High NEFA concentrations in the ovarian follicle are negatively correlated with the production of $17 \beta$-estradiol (E2), which plays a significant role in expressing physiological and behavioral signs of estrus in cows (Jorritsma et al., 2003; Leroy et al., 2008).

\section{Lipolysis, ketogenesis and welfare on farms}

There are different systems for the evaluation of welfare on cow farms, such as the Welfare Quality ${ }^{\circledR}$ scoring system, an excellent model based on evaluating welfare using cow examination data. . This system was used in our experiments. It provides evaluation of welfare through four principles: principle of good housing, principle of good health, principle of good nutrition and principle of appropriate behavior. Welfare evaluation on farms can affect lipolysis and ketogenesis in cows housed on these farms. This influence is particularly apparent in early lactation (Belić et al., 2013, 2015). In cows on farms with a reduced score of welfare, higher concentrations of cortisol and signs of metabolic 
stress are present and are reflected in higher NEFA, BHB and bilirubin concentrations and reduced concentrations of glucose and urea. The most important principles of welfare affecting the metabolic status of cows are principles of good health and nutrition. Results showed that it is possible to use metabolic parameters of cows to evaluate welfare but further research is needed.

\section{References}

Adela P., Zinveliu D., Pop R.Al., Andrei S., Kiss E. (2006): Antioxidant status in dairy cows during lactation. Bulletin of university of agricultural sciences and veterinary medicine Cluj-Napoca, 63: 130-135.

Beerda B., Kornalijnslijper J.E., van der Werf J.T.N., Noordhuizen-Stassen E.N., Hopster H. (2004): Effects of Milk Production Capacity and Metabolic Status on HPA Function in Early Postpartum Dairy Cows. Journal of Dairy Science, 87: 2094-2102.

Bell A., Bauman D. (1997): Adaptations of glucose metabolism during pregnancy and lactation. Journal of Mammary Gland Biology and Neoplasia, 2: 265-278.

Belić B., Cincović M., Lakić I., Đoković R., Petrović M., Ježek J., Starič J. (2018): Metabolic Status of Dairy Cows Grouped by Anabolic and Catabolic Indicators of Metabolic Stress in Early Lactation. Acta Scientiae Veterinariae, 2018. 46 (in press)

Belić B., Cincović M.R., Stevančević M., Toholj B., Popović Vranješ A., Pejanović R., Davidov I., Potkonjak A., Stančić I. (2015): Influence of metabolic profile in early lactation and welfare score of farm to milk production and service period in dairy cows. Contemporary agriculture, 64: 65-71.

Belić B., Cincović M., Popović Vranješ A., Pejanović R., Došenović M. (2013): Metabolic characteristics of cows on farms with different welfare score. Contemporary agriculture, 62:236-241

Belić B., Grubac S., Cincović M., Plavša N., Popović-Vranješ A., Pejanović R., Delic B., Hristovska T. (2014): Uticaj metaboličkog i endokrinog statusa na proizvodnju mleka kod krava u ranoj laktaciji. Letopis naučnih radova Poljoprivrednog fakulteta, 38: 172180.

Bernabucci U., Ronchi B., Lacetera N., Nardone A. (2005): Influence of body condition score on relationships between metabolic status and oxidative stress in periparturient dairy cows. Journal of Dairy Science, 88: 2017-2026.

Bernabucci U., Ronchi B., Lacetera N., Nardone A. (2002): Markers of oxidative status in plasma and erythrocytes of transition dairy cows during hot season. Journal of Dairy Science, 85: 2173-2179.

Bertoni G., Lombardelli R., Piccioli-Cappelli F., Blum J. (2002): Basal levels and diurnal variations of some hormones and metabolites in blood of dairy cows treated daily with rbST in early and late lactation. Italian Journal of Animal Science, 1: 127-141.

Busato A., Faissler D., Kupfer U., Blum J.W. (2002): Body condition scores in dairy cows: Associations with metabolic and endocrine changes in healthy dairy cows. Journal of veterinary medicine. A, Physiology, pathology, clinical medicine, A49: 455-460.

Chapinal N., Carson M.E., LeBlanc S.J., Leslie K.E., Godden S., Capel M., Santos J.E.P., Overton M.W., Duffield T.F. (2012): The association of serum metabolites in the transition period with milk production and early-lactation reproductive performance. Journal of Dairy Science, 95: 1301-1309. 
Cincović M.R. (2016): Metabolički stres krava. Monografija. Poljoprivredni fakultet Novi Sad - Departman za veterinarsku medicinu.

Cincović M.R., Belić B., Radojičić B., Hristov S., Đoković R. (2012): Influence of lipolysis and ketogenesis to metabolic and hematological parameters in dairy cows during periparturient period. Acta veterinaria (Beograd), 62: 429-444.

Cincović M.R., Belić B., Stevančević M., Lako B., Toholj B., Potkonjak A. (2010): Diurnal variation of blood metabolite in dairy cows during heat stress. Contemporary agriculture, 59: 300-305.

Cincović M.R., Belić B., Vidović B., Krčmar LJ. (2011): Reference values and frequency distribution of metabolic parameters in cows during lactation and in pregnancy. Contemporary agriculture, 60: 175-182.

Cincović M.R., Starič J. (Ed.) (2017): Laboratorijska istraživanja metaboličkog statusa goveda. Monografija. Poljoprivredni fakultet Novi Sad - Departman za veterinarsku medicinu i Veterinarska fakulteta Ljubljana.

Cincović M., Belić B., Stančić I., Dosenovic M., Stojanac N., Stevančević O. (2014): Ispitivanje veze između metaboličkog i endokrinog statusa krava u ranoj laktaciji i dužine servis perioda. Letopis naučnih radova Poljoprivrednog fakulteta, 38: 181-190.

Contreras G.A., O'Boyle, Herdt T.H., Sordillo L.M. (2010): Lipomobilization in periparturient dairy cows influences the composition of plasma nonesterified fatty acids and leukocyte phospholipid fatty acids. Journal of Dairy Science, 93: 2508-2516.

Dann H.M., Drackley J.K. (2005): Carnitine palmityoltransferase I in liver of periparturient dairy cows: effects of prepartum intake, postpartum induction of ketosis, and periparturient disorders. Journal of Dairy Science, 88: 3851-3859.

Drackley J.K., Dann H.M., Douglas G.N., Janovick Guretzky N.A., Litherland N.B., Underwood J.P., Loor J.J. (2005): Physiological and pathological adaptations in dairy cows that may increase susceptibility to periparturient diseases and disorders. Italian Journal of Animal Science, 4: 323-344.

Drackley J.L. (1999): Biology of Dairy Cows During the Transition Period: the Final Frontier? Journal of Dairy Science, 82: 2259-2273.

Đoković R., Ilić Z., Kurćubić V., Petrović M., Dosković V. (2011): Functional and morphological state of the liver in Simmental dairy cows during transitional period. Revue de Médecine Vétérinaire, 162: 574-579.

Đoković R., Šamanc H., Nikolić Z., Bošković-Bogosavljević S. (2007): Changes in blood values of glucose, insulin and inorganic phosphorus in healthy and ketotic cows after intravenous infusion of propionate solution. Acta Veterinaria Brno, 76: 533-539.

Friggens N.C. (2003): Body lipid reserves and the reproductive cycle: towards a better understanding. Livestock Production Science, 83: 219-236.

Georgieva N.V. (2005): Oxidative stress as a factor of disrupted ecological oxidative balance in biological systems - a review. Bulgarian Journal of Veterinary Medicine, 8: 1-11.

Gross J., van Dorland H.A., Bruckmaier R.M., Schwarz F.J. (2011): Performance and metabolic profile of dairy cows during a lactational and deliberately induced negative energy balance with subsequent realimentation. Journal of Dairy Science, 94: 1820-1830.

Hachenberg S., Weinkauf C., Hiss S., Sauerwein H. (2007): Evaluation of classification modes potentially suitable to identify metabolic stress in healthy dairy cows during the peripartal period. Jorunal of Animal Science, 85: 1923-1932. 
Holtenius K., Persson Waller K., Essén-Gustavsson B., Holtenius P., Hallén Sandgren C. (2004): Metabolic parameters and blood leukocyte profiles in cows from herds with high or low mastitis incidence. Veterinary Journal, 168: 65-73.

Husvéth F., Karsai F., Gaal T. (1982): Peripartal fluctuations of plasma and hepatic lipid components in dairy cows. Acta veterinaria Academiae Scientiarum Hungaricae, 30: 97112.

Jorritsma R., Wensing T., Kruip T.A.M., Vos P.L.A.M., Noordhuizen J.P.T.M. (2003): Metabolic changes in early lactation and impaired reproductive performance in dairy cows. Veterinary Research, 34: 11-26.

Kessel S., Stroehl M., Meyer H.H.D., Hiss S., Sauerwein H., Schwarz F.J., Bruckmaier R.M. (2008): Individual variability in physiological adaptation to metabolic stress during early lactation in dairy cows kept under equal conditions. Journal of Animal Science, 86: 29032912.

Konig B.A., Parker D.S., Oldham J.D. (1979): Acetate and palmitate kinetic in lactating dairy cows. Annals of veterinary research, 10: 368-372.

Leroy J.L.M.R., Vanholder T., Van Knegsel A.T.M., Garcia-Ispierto I., Bols P.E.J. (2008): Nutrient prioritization in dairy cows early post partum: Mismatch between metabolism and fertility? Reproduction in Domestic Animimals, 43(Suppl.2): 96-103.

Littledike, E. T., Whipp S.C., Witzel D.A., Baetz A.L. (1970): Insulin, corticoids, and parturient paresis. Academic Press, New York, NY.

Loor J.J., Dann H.M., Everts R.E., Oliveira R., Green C.A., Janovick Guretzky N.A., Rodriguezzas S.L., Lewin H.A., Drackley J.K. (2005): Temporal gene expression profiling of liver from periparturient dairy cows reveals complex adaptive mechanisms in hepatic function. Physiological Genomics, 23: 217-226.

Loor J.J., Everts R.E., Bionaz M., Dann H.M., Morin D.E., Oliveira R., Rodriguez-Zas S.L., Drackley J.K., Lewin H.A. (2007): Nutrition-induced ketosis alters metabolic and signaling gene networks in liver of periparturient dairy cows. Physiological Genomics, 32: $105-116$.

Murondoti A., Jorritsma R., Beynen A.C.,Wensing T., Geelen M. (2004): Activities of the enzymes of hepatic gluconeogenesis in periparturient dairy cows with induced fatty liver. Journal of Dairy Research, 71: 129-134.

Nowroozi Asl A., Nazifi S., Rowshan Ghasrodashti A., Olyaee A. (2011): Prevalence of subclinical ketosis in dairy cattle in Southwestern Iran and detection of cutoff point for NEFA and glucose concentrations for diagnosis of subclinical ketosis. Preventive Veterinary Medicine, 100: 38-43.

Ospina P.A., Nydam D.V., Stokol T., Overton T.R. (2010): Associations of elevated nonesterified fatty acids and $\beta$-hydroxybutyrate concentrations with early lactation reproductive performance and milk production in transition dairy cattle in the northeastern United States. Journal of Dairy Science, 93: 1596-1603.

Ospina P.A., Nydam D.V., Stokol T., Overton T.R. (2010): Evaluation of nonesterified fatty acids and $\beta$-hydroxybutyrate in transition dairy cattle in the northeastern United States: Critical thresholds for prediction of clinical diseases. Journal of Dairy Science, 93: 546554.

Pedernera M., Celi P., García S.C., Salvin H.E., Barchia I., Fulkerson W.J. (2010): Effect of diet, energy balance and milk production on oxidative stress in early-lactating dairy cows grazing pasture. The Veterinary Journal, 186: 352-357. 
Rastani R.R., Lobos N.E., Aguerre M. J., Grummer R.R., Wattiaux M A. (2006): Relationships between blood urea nitrogen and energy balance or measures of tissue mobilization in Holstein cows during the periparturient period. The Professional Animal Scientist, 22: 382-385.

Reynolds C.K., Huntington G.B., Tyrrell H.F., Reynolds P.J. (1998): Net portal-drained visceral and hepatic metabolism of glucose, L-lactate, and nitrogenous compounds in lactating Holstein cows. Journal of Dairy Science, 71: 1803-1812.

Roberts T., Chapinal N., LeBlanc S.J., Kelton D.F., Dubuc J., Duffield T.F. (2012): Metabolic parameters in transition cows as indicators for early-lactation culling risk. Journal of Dairy Science, 95: 3057-3063.

Scalia D., Lacetera N., Bernabucci U., Demeyere K., Duchateau L., Burvenich C. (2006): In Vitro Effects of Nonesterified Fatty Acids on Bovine Neutrophils Oxidative Burst and Viability. Journal of Dairy Science, 89:147-154.

Sordillo L.M., Contreras G. A., Aitken S.L. (2009): Metabolic factors affecting the inflammatory response of periparturient dairy cows. Animal Health Research Reviews, 10: 53-63.

Suriyasathaporn W., Heuer C., Noordhuizen-Stassen E., Schukken Y.H. (2000): Hyperketonaemia and the impairment of udder defense: a review. Veterinary Resesearch, 31: 397-412.

Šamanc H.A. (2009): Bolesti organa za varenje goveda. Beograd.

Šamanc H., Gvozdić D., Fratrić N., Kirovski D., Djokovic R., Sladojević Ž., Cincović M. (2015): Body condition score loss, hepatic lipidosis and selected blood metabolites in Holstein cows during transition period. Animal Science Papers and Reports, 33: 3547.

Tharwat M., Endoh D., Oikawa S. (2012): DNA damage in peripheral blood mononuclear cells and neutrophils of dairy cows during the transition period. Open Veterinary Journal, 2: 65-68.

Van Den Top A.M., Geelen M.J.H., Wensing T., Wentink, G.H., Van’t Klooster A.T., Beynen A.C. (1996): Higher postpartum hepatic triacylglycerol concentrations in dairy cows with free rather than restricted access to feed during the dry period are associated with lower activities of hepatic glycerolphosphate acyltransferase. Journal of Nutrition, 126: 76-85.

Van Saun R.J. (2000): Metabolic Profiling: Assessing nutritional status of the transition cow. Washington State VMA Annual Scientific Proceedings: p.1-8.

Yamamoto O., Oikawa S., Katoh N. (1995): Enzyme-linked immunosorbent assay for serum apolipoprotein B-100, a major triglyceride-transport protein in dairy cows. American Journal of Veterinary Research, 56, 11:1413-1417.

Zhang Z.G., Li X.B., Gao L., Li Y.F., Liu G.W., Wang H.B., Wang Z. (2011): Serum antioxidant capacity of dairy cows with subclinical ketosis. Veterinary Record, 168: 22. 


\title{
LIPOLIZA I KETOGENEZA KOD KRAVA U RANOJ LAKTACIJI
}

\author{
Ivana Lakić ${ }^{1}$, Marko R. Cincović ${ }^{1}$, Branislava Belić ${ }^{1}$, Radojica \\ Đoković $^{2}$, Mira Majkić ${ }^{1}$, Miloš Ž. Petrovićé ${ }^{2}$, Sandra Nikolić ${ }^{1}$ \\ ${ }^{1}$ Univerzitet u Novom Sadu, Poljoprivredni fakultet, Departman za veterinarsku \\ medicinu; Trg Dositeja Obradovića 8, 21000 Novi Sad, Srbija \\ ${ }^{2}$ Univerzitet u Kragujevcu, Agronomski fakultet Čačak, Cara Dušana 34, Čačak, \\ Srbija
}

\section{Rezime}

Peripartalni metabolički stres se odlikuje povećanom lipidnom mobilizacijom kada raste koncentracija neesterifikovanih masnih kiselina (NEFA) i povećanom ketogenezom kada raste koncentracija beta hidroksibutirata (BHB). NEFA se metabolišu u svim tkivima, ali je centralni organ metabolizma jetra. Mogući su sledeći procesi: a) potpuna oksidacija masnih kiselina, b) delimična oksidacija i sinteza ketonskih tela (BHB) kada nastaje ketoza, c) formiranje triglicerida iz NEFA koji se mogu dalje transportovati ili ostati u jetri kada nastaje masna jetra. Pored navedenog, povećana lipoliza i ketogeneza dovode do oksidativnog stresa jer koncentracija MDA i/ili TBARS pozitivno korelira sa koncentracijom NEFA i BHB. Povišena koncentracija NEFA u peripartalnom periodu dovodi do promena u celularnom imunološkom odgovoru modifikacijom intracelularnih signala, kontrolom ekspresije gena, aktivacijom transkripcionih faktora, indukcijom apoptoze i modifikujući produkciju lipidnih aktivnih medijatora. Povećana proporcija krava sa visokom koncentracijom NEFA i BHB u stadu dovodi do umanjenja u produkciji mleka na kraju standardne laktacije od 305 dana. Koncentracija NEFA se može dovesti u vezu sa postpartalnom ovarijalnom aktivnošću, posebno ako se zna da koncentracija NEFA u krvi oslikava i koncentraciju NEFA u folikularnom fluidu jajnika. Kod krava na farmama sa nižim skorom dobrobiti prema principu dobrog zdravlja i dobre ishrane postoji viša koncentracija kortizola, NEFA, BHB i bilirubina i snižena koncentracija glukoze i uree. Koncentracija NEFA i BHB u ranoj laktaciji može se koristiti za procenu metaboličke adaptacije krava u prvih osam nedelja posle teljenja. Za procenu metaboličke adaptacije mnogo je značajnija povećana lipoliza od opadanja anaboličkih pokazatelja kao što su insulin i IGF-I.

Ključne reči: krave, metabolički profil, rana laktacija, stres. 